\title{
TRAINING IN ONCOPLASTIC AND RECONSTRUCTIVE BREAST SURGERY: ANALYSIS OF TRAINING IN AMERICA AND IN THE EUROPEAN UNION WITH THE BRAZILIAN REALITY
}

\author{
Formação em cirurgia oncoplástica e reconstrutiva da mama: análise \\ da formação na América e na União Europeia com a realidade brasileira
}

Douglas de Miranda Pires ${ }^{1,2}$, Orivaldo Gazoto Junior ${ }^{2,3 *}$, Carolina Nazareth Valadares ${ }^{4}$, Raffaela Levy Andrade ${ }^{4}$

\section{ABSTRACT}

The reconstructive and aesthetic breast surgery is a major breakthrough for the treatment of women fighting cancer. An advantage for the patient is the reduction of surgical treatment to one professional, besides the psychological and aesthetic relief of having her breast comfortably reconstructed by the doctor who is already accompanying her in the treatment of the disease. Considering the advances in oncological breast surgery, fhe ideal surgical procedure is one that achieves local control of the disease by maintaining the symmetry of the breast with immediate reconstruction. Plastic surgery techniques can be used in breast cancer surgery. The original focus is on improving the quality of life of oncological patients undergoing treatments that may be more effective in the aesthetic and functional point of view from the perspective of traditional techniques of breast conservation. Formation and training of professionals able to treat breast cancer is an innovative concept that brings discussions to the scientific community. Specific studies are required to standardize oncoplastic training. Training in reconstructive and aesthetic breast surgery also brings about new perspectives of surgical research related to aesthetic results, quality of life and local control, as well as the optimization of operative time, reducing adverse effects and costs. This study aimed to evaluate the main existing techniques, the training time for specialization in the context of Brazilian reality and whether it is necessary to change the current training model. This review is based on the conviction shown in other publishing studies (in press), which demonstrate the best way and the best work load for the improvement of the mastologist regarding oncoplastic and reconstructive breast surgeries.

KEYWORDS: Breast neoplasm; mammaplasty; education.

Study carried out in Instituto de Ensino e Pesquisa from Santa Casa de Misericórdia de Belo Horizonte - Belo Horizonte (MG), Brazil.

${ }^{1}$ Mastology Clinic, Santa Casa de Belo Horizonte - Belo Horizonte (MG), Brazil.

2Instituto de Ensino e Pesquisa, Santa Casa de Belo Horizonte - Belo Horizonte (MG), Brazil.

${ }^{3}$ Mastology Clinic, Hospital Regional Rosa Pedrossian - Campo Grande (MS), Brazil.

${ }^{4}$ Santa Casa de Belo Horizonte - Belo Horizonte (MG), Brazil.

*Corresponding author: ogazoto@uol.com.br

Conflict of interests: nothing to declare.

Received on: 01/23/2017. Accepted on: 05/30/2017 


\section{RESUMO}

A cirurgia reparadora e estética da mama representa um grande avanço para o tratamento de mulheres que lutam contra o câncer. Uma das vantagens para a paciente é a diminuição de procedimentos cirúrgicos e tratamentos com mais de um profissional, além do alívio psicológico e estético de ter sua mama reconstruída de forma confortável pelo médico que já a acompanha no tratamento da doença. No que diz respeito aos avanços das cirurgias oncológicas da mama, deve-se levar em consideração o procedimento ideal com margens livres e o controle local adequado da doença, a reconstrução imediata da mama de forma simétrica e, por fim, a transposição de técnicas da cirurgia plástica para a cirurgia de câncer de mama. O foco original é a melhoria da qualidade de vida das pacientes oncológicas submetidas a tratamentos que podem ser mais eficazes do ponto de vista estético-funcional sob a ótica das técnicas tradicionais de conservação mamária. A formação e a capacitação de todos os profissionais aptos ao tratamento do câncer de mama é um conceito inovador e trará discussões e novos desafios ao meio científico, o que instiga a possibilidade de criar estudos específicos que levem em consideração a opinião da sociedade no intuito de padronizar a formação em oncoplastia. A pesquisa científica é necessária para avaliar muitos outros aspectos relacionados à oncoplastia, como o resultado estético, a qualidade de vida das pacientes e o controle local da doença, bem como a otimização do tempo operatório e a redução de efeitos adversos e custos. O presente estudo visou avaliar as principais técnicas existentes, o tempo para formação dessa especialização no contexto da realidade brasileira e se há necessidade de mudanças no modelo de formação dos profissionais que optarem por segui-la. Esta revisão baseia-se na convicção mostrada em trabalhos em editoração (in press) que demonstram a melhor forma e a melhor carga horária para aprimoramento do mastologista em técnicas de cirurgia oncoplástica e reconstrutiva da mama referendada em observação.

PALAVRAS-CHAVE: Neoplasia da mama; mamoplastia; educação.

\section{INTRODUCTION}

Oncoplastic surgery in the treatment of breast cancer favors breast surgeons in the contexts of breast reconstruction and patient care, providing better aesthetic results without sacrificing the oncological treatment. The interaction between plastic surgery and mastology techniques originated a new approach to surgical training that aims to facilitate the treatment of this neoplasm. Technological advancements and benefits provided have already been discussed and presented in various global scenarios ${ }^{1}$.

Professionals from different fields came together to share experiences and confront basic principles and techniques involved. Oncoplastic and reconstructive surgery of the breast was introduced in postgraduate course programs in 2010, during the Annual Clinical Congress of the American College of Surgeons (ACS), in San Francisco, California, with the participation of 120 professionals specializing in breast surgery, general surgery and plastic surgery. In this event, wellknown oncoplastic surgeons, such as Dr. Elizabeth Beahn and Prof. Melvin Silverstein, brought to light a number of relevant aspects of oncoplasty, such as indications, contraindications, postoperative radiotherapy, cost-effectiveness and variations in surgical time ${ }^{1}$.

Most patients diagnosed with breast cancer in the United States are currently treated by a general surgeon specialized in cancer surgery. This scenario is different in Brazil, where most of the surgeries are performed by breast surgeons with training in general surgery, oncologic surgery and/or gynecology and obstetrics ${ }^{2}$.
The objective of this study was to analyze the discussions about the different formations of the breast surgeons in the studies published in the European Union and the works published by their direct collaborators to contrast and compare the different views put forward by each professional. The present study evaluated the different models for the training of breast reconstruction worldwide and their results. We focused our assessment on the essential criteria for candidates to participate in the training and performed a curricular analysis in the oncology field. Finally, we assessed whether significant changes in the current model of breast reconstruction surgery training in Brazil are required.

\section{METHODS}

The present study is a review of the scientific literature on the training of surgeons to perform oncoplastic and reconstructive breast surgeries. According to $\mathrm{Gil}^{3}$,a bibliographical research is carried out using publications that are already prepared, especially books and scientific papers. The present bibliographic work is a literature review of published works, master's thesis, electronic magazines and federal council bulletins. Our search terms included oncoplastic, surgeon training, reconstructive surgery of the breast and their equivalent in Portuguese (oncoplastia, formação do cirurgião and cirurgia reparadora da mama) with no period limits. In the result section, we discussed different points of view that form the training base considering time and number of patients adequate to oncoplastic surgery referral, as well as the amplitude of the clinical situation. 


\section{OBJECTIVES}

\section{General Objectives}

To discuss methodological, operational and training aspects of professionals in oncoplastic and reconstructive breast surgery in Brazil.

\section{Specific objectives}

- To identify the time required for the training of medical professionals in oncoplastic and reconstructive breast surgery;

- To know and define the methodology applicable to the training of oncoplastic and reconstructive breast surgery (postgraduate programs, specialization courses, extension courses, continuing education, modular courses);

- To establish the professional practice time in oncoplastic and reconstructive breast surgery; and

- To identify the professional profile indicated for the performance of oncoplastic and reconstructive breast surgery.

\section{RESULTS}

\section{Oncoplastic and reconstructive breast surgery scenario in several continents}

The oncoplastic and reconstructive surgery of the breast techniques discussed worldwide seem to have parameterization with the Brazilian reality. The basis of reconstructive surgeries applied both in the US and in the European Union has the same basic surgical features for tumor removal and reconstitutions by flaps or breast implants. In relation to basic training, not many differences have been observed, since most professionals are surgeons - breast surgeons, plastic surgeons or oncologists. It should be emphasized that, although reconstructive surgeries are performed mostly by professionals of various specializations, the aesthetic part is almost entirely reserved for breast surgeons with training in oncoplastic and reconstructive breast surgeries ${ }^{4}$.

According to Mazzei ${ }^{5}$, mastology, oncology and general surgery professionals should have mastery over oncoplastic and reconstructive breast surgery techniques in order to plan and customize the treatment for each patient. This, undoubtedly, has led to protests by plastic surgeons who advocate oncoplastic surgery is an exclusive practice for professionals in this field. This medical progress can aggregate plastic surgery techniques, adapting them to the oncological profile. The various Brazilian institutions that offer training in this specialty train residents to perform and develop the process correctly. Several international health centers find difficulties in adding plastic surgeons to teams for different reasons, which forces breast surgeons to acquire more experience in the reconstructive area ${ }^{5}$.
Baildam $^{6}$ analyzes that the legacy of historical surgical training meant that, until recently, few surgeons were equipped to offer this surgical approach to cancer, which simultaneously involves aesthetics and reconstruction. The author states that the change in the training of these professionals came to definitively change this reality. According to him, in the United Kingdom, only in the last decade, about 90 surgeons were awarded with high level scholarships. The basic course consists of 12 months of oncoplastic surgery training in 9 training centers performed by breast surgeons and plastic surgeons in an integrated manner. This approach seems to improve the quality of surgical care for the benefit of women, in addition to indicating a renovation in the field of breast surgery, far from the procedures based purely on resection techniques that remained unchanged for many decades.

Therefore, the outcome of the process in the UK has been marked by the interest in training among surgeons, so as to continue investing in a career in the breast surgery field, thus encouraging national scholarships and making them highly competitive. Some countries are already prepared to absorb this new medical specialty and have strategies in a partnership with the government to support the benefits of this type of surgery. The psychological impact on the patient and the increase in survival rates are numerically enthusiastic. Table 1 shows the training requirements to complete specialization in different countries ${ }^{7-11}$.

\section{Oncoplastic Surgery in Brazil}

According to Brazilian Law n. 12,802, sanctioned on April 24, 2013, when there are technical conditions, reconstruction shall be performed in the same surgery. In case of the immediate reconstruction is impossible, the patient shall be referred for followup and submitted to surgery soon after reaching the required clinical conditions ${ }^{12}$. This law was elaborated by Congresswoman Rebecca Garcia, who fought for more than five years for this service to be offered by the Brazilian public unified health system (SUS). The deputy reports that this law originated from feminist movements that believed the mutilation left by a tumor removal surgery would cause psychological damage as an effect of low self-esteem ${ }^{13}$

After the law passed, some medical societies - such as the Brazilian Society of Mastology (SBM), the Brazilian Society of Plastic Surgery (SBCP) and the National Cancer Institute (INCA) - took actions to include oncoplasty as a medical complement in academic and extensive training for different specialties, graduating and training professionals who work in the fight against breast cancer to perform the reconstructive treatment in the early stages of diagnosis. According to Ruffo ${ }^{14}$, in an interview with Onconews, oncology safety must be aligned with aesthetic results to promote the better quality of life of patients. In addition, there seems to be the need 
for more intensive training of our professionals. The SBM has identified this gap even among residency graduates who have recently undergone medical licensing examination. In this sample, it is possible to see that $20 \%$ of these medical residency programs still offer very little or almost no oncoplastic training $^{14}$. In 2010, in Brazil, five courses in oncoplasty were started (post-graduation, specialization or continuing or modular education), which are described in Table 2.

In Brazil, the requirements to apply for these courses are medical specialty in oncology, breast surgery or plastic surgery. The selection process includes curricular analysis, specific test and interview.

Table 1. Basic training for oncoplastic specialization in Brazil and in other countries.

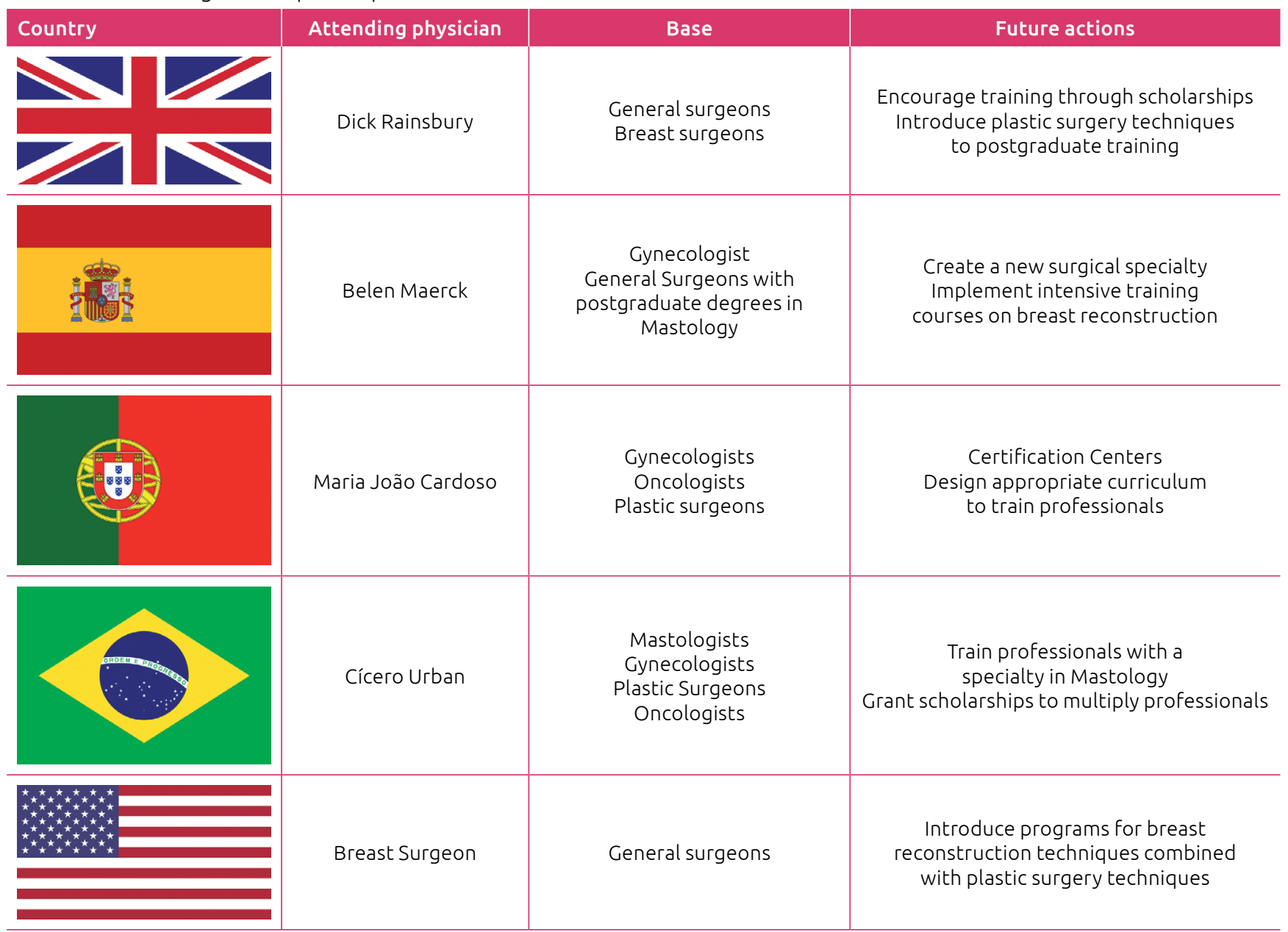

Source: Cardoso MJ, et al. ${ }^{27}$

Table 2. Training centers in oncoplasty in Brazil.

\begin{tabular}{|c|c|c|c|c|}
\hline Institution & City & Physician in charge & Certification & Workload \\
\hline Santa Casa de Belo Horizonte & Belo Horizonte & Douglas Pires & Graduate diploma & $\begin{array}{c}540 \mathrm{~h} \\
\text { (15 months) }\end{array}$ \\
\hline Hospital do Câncer de Barretos & Barretos & Gustavo Zucca Matthes & $\begin{array}{l}\text { Specialization } \\
\text { course }\end{array}$ & $\begin{array}{c}380 \mathrm{~h} \\
\text { (19 months) }\end{array}$ \\
\hline Hospital Araújo Jorge de Goiânia & Goiânia & Régis Paulinelli & $\begin{array}{l}\text { Continuing } \\
\text { education }\end{array}$ & $\begin{array}{c}240 \mathrm{~h} \\
\text { (10 months) }\end{array}$ \\
\hline Beneficência Portuguesa de São Paulo & São Paulo & Vilmar Marques & Extension course & $\begin{array}{c}240 \mathrm{~h} \\
\text { (10 months) }\end{array}$ \\
\hline $\begin{array}{l}\text { Hospital das Clínicas da Universidade } \\
\text { Federal do Rio Grande do Sul }\end{array}$ & Porto Alegre & Jorge Biazús & Modular course & $\begin{array}{l}60 \mathrm{~h} \\
\text { Module }\end{array}$ \\
\hline
\end{tabular}

Source: Pires DM. Tcc - Orivaldo Gazoto Jr. [personal message] Message received on April 13, 2016. 


\section{Oncoplasty development}

Today's medical career requires specific refinements in each area. Patients are aware that specialized care is available for certain types of diseases, and realize that the care provided by a specialist is better than the service provided by a general surgeon. Thus, medical specialists who provide this type of care will, in great demand, be a byproduct of a well-informed society ${ }^{15}$.

Physicians who graduated in general surgery seem to respond well to these demands, seeking professional distinction in record numbers. It is estimated that half of the general surgeons acquire, each year, a certificate in some subspecialty recognized by the American Board of Medical Specialties ${ }^{16}$. Although the data show high volume of mortality by the hands of general surgeons, physicians who seek training are more assertive in complex surgical procedures such as oncology surgery. Oncoplasty came as an aggregating byproduct that, in addition to generating good results against breast cancer, promotes an increase in the quality of life of the patient. Oncoplasty also provides improvements in self-esteem by preserving a part of the body that, for a long time during the fight against this type of cancer, used to be mutilated ${ }^{17}$.

\section{The emergence of oncoplasty and fundamental techniques}

In the 1990s, the German surgeon Audretsch coined the term oncoplastic surgery to name the procedures that allowed tumor resection followed by immediate breast reconstruction, with restorative techniques that applied the principles of cosmetic surgery and its variations (considering tumor location in the different quadrants of the breast and the relationship between breast volume and tumor size). After that, this new technique for the handling of breast cancer spread in Europe and the United States. Multidisciplinary work with the integration of oncologists and plastic surgeons began with excellent results. The immediate reconstruction of the breast was consecrated as a routine practice of major importance. Oncoplasty or oncoplastic surgery is the union of plastic surgery techniques directed to the reconstruction of the breast in the treatment against mammary tumors. From the 1980s and especially in the 1990s, part of the breast started to be preserved in cases of initial cancer. Some studies have shown that breast conservation enhances the quality of life and the self-esteem, and the fear of disease recurrence is not different between patients undergoing conservative breast therapy and mastectomy. However, there are still insufficient studies regarding the impact of oncoplastic surgery on local recurrences and overall disease-free survival. In addition, data regarding their aesthetic results are also limited. Thus, everything should be done to increase the breast conservation rate. However, the aesthetic result may vary between the different conservative procedures. It is extremely important to follow the surgical guidelines and to use oncoplastic techniques when indicated, especially in patients with larger tumors ${ }^{4}$. Partial breast reconstruction techniques were also developed using the same principles of breast aesthetic surgeries, such as suspension, reduction and placement of silicone prostheses ${ }^{1}$. In 1994, a division of the breast into quadrants was instituted, which allowed the prior and planned analysis of the oncoplastic techniques to be used ${ }^{17}$.

Breast oncoplastic surgery is based on some fundamental techniques: reconstructions with and without flaps and breast implants $^{19}$ (Tables 3-5).

\section{Oncoplastic surgery and the Brazilian public service}

In 2016, 57,960 new cases of breast cancer were estimated in Brazil $^{20}$. Oncoplasty may be able to improve the outcome in the treatment of most patients, including those treated by the SUS. In this context, the diffusion of professionals specialized in oncoplasty is essential, aiming at the benefit to patients submitted to breast surgery for cancer treatment. Currently, the number of Brazilian professionals qualified in oncoplasty is limited, especially those in the public health sector ${ }^{21}$. In Brazil, breast surgeons are the target audience in oncoplasty training, which is an excellent starting point for defining the purpose of this

Table 3. Types of techniques without flaps.

\begin{tabular}{|c|c|c|}
\hline Type & Breast size & Tumor location \\
\hline Lower pedicle & $\begin{array}{l}\text { Small, medium } \\
\text { and large }\end{array}$ & $\begin{array}{l}\text { Lateral and medial } \\
\text { and superior } \\
\text { quadrants }\end{array}$ \\
\hline Upper pedicle & Medium and large & Lower quadrants \\
\hline Round block & Small and medium & $\begin{array}{l}\text { Periareolar and } \\
\text { central quadrant }\end{array}$ \\
\hline
\end{tabular}

Source: Mesquita $\mathrm{M}^{28}$.

Table 4. Types of techniques with flaps.

\begin{tabular}{l|c|c} 
Type & Correction type & Risks \\
\hline TRAM flap & $\begin{array}{c}\text { Post-mastectomy } \\
\text { defects }\end{array}$ & High \\
\hline $\begin{array}{l}\text { Latissimus dorsi } \\
\text { muscle rotation }\end{array}$ & $\begin{array}{c}\text { Post-quadrant } \\
\text { defects }\end{array}$ & Reduced \\
\hline
\end{tabular}

TRAM: transverse abdominal muscle. Source: Mesquita $\mathrm{M}^{28}$.

Table 5. Flap reconstruction.

\begin{tabular}{l|c} 
Breast type & \multicolumn{1}{|c}{ Indication } \\
\hline $\begin{array}{l}\text { Implants or } \\
\text { expanders }\end{array}$ & $\begin{array}{r}\text { All sizes but more appropriate to small, } \\
\text { medium or absent breasts }\end{array}$ \\
\hline Source: Mesquita $\mathrm{M}^{28}$ &
\end{tabular}

Source: Mesquita M²8. 
study. The emphasis of oncoplastic specialization courses is the improvement of existing surgical techniques towards aesthetic breast reconstruction ${ }^{5}$.

In a publication of the SBM magazine, from São Paulo, Mazzei (2010) states: "Our surgical practice underwent major and important modifications in the last years with conservative and less mutilating techniques, which allow us to preserve more of the cutaneous tissue, the nipple-areolar complex, the mammary gland and the axila" ${ }^{\text {".Today, breast surgeons }}$ must have mastery over oncoplastic surgery techniques in order to plan and provide the most appropriate treatment for patients. This undoubtedly has created protests on the part of plastic surgeons, who consider themselves to be exclusive for this specialty. It is a fact that the interaction between teams allows knowledge sharing and the adaptation of plastic surgery techniques to the oncological profile. Therefore, institutions that offer training in this specialty certainly cover some of the oncoplastic techniques and must increasingly improve this approach"5. The point defended by Mazzei portrays that oncoplastic surgeons must have a curriculum in oncology $y^{5}$ in order to provide the most appropriate treatment for their patients. The data in Table 6 were published by SUS and refer to the medical actions for breast repair surgery. The figures reveal that the number of procedures is growing, which is encouraging. However, the rate of repair surgery does not exceed $10 \%$ in the states analyzed.

\section{DISCUSSION}

After evaluating some authors of oncoplasty worldwide, we observed that three specialties have greater demand for oncoplastic certification: breast surgery, plastic surgery and oncology surgery. Most of these specialties are based both in the United States and in the European Union. These professionals seek certification as a process of medical career improvement, aiming to combine treatment with psychological and aesthetic features. Although Brazil is a country of continental dimensions, not all its regions have multidisciplinary teams.

Table 6. Number of reparative surgeries in some Brazilian states.

\begin{tabular}{l|c|c|c} 
State & Procedures & $\begin{array}{c}\text { Repair } \\
\text { surgery }\end{array}$ & $\%$ \\
\hline São Paulo & 8,058 & 386 & 4.8 \\
\hline Rio de Janeiro & 3,951 & 220 & 5.6 \\
\hline Minas Gerais & 2,429 & 88 & 3.6 \\
\hline Ceará & 2,242 & 15 & 0.7 \\
\hline Pernambuco & 2,155 & 54 & 2.5 \\
\hline Brasil & 32,548 & 1074 & 3.3 \\
\hline
\end{tabular}

Source: Resende $\mathrm{MA}^{29}$.
Some regions are faced with the shortage of specialized physicians, which forces patients to travel in order to seek breast cancer treatment, consequently reducing survival rates. A trained oncoplastic practitioner, by having support material, will considerably reduce the number of deaths due to late treatment or absence of treatment, contributing to an effective public health program.

\section{Mastology point of view}

The surgical treatment of benign and malignant mammary neoplasias, as well as the approach of hypertrophies and mammary asymmetries, requires mastologists to have the technical knowledge previously applied by plastic surgeons. The contralateral breast symmetry among patients undergoing conservative surgical treatments should be considered. Oncological mammoplasty adapts mammoplasty to the surgical treatment of breast cancer. It is a well-defined surgical strategy to treat selected cases that promotes an increase in conservative surgery indications $\mathrm{s}^{22}$. Reduction mammoplasty techniques appear to be safe for treating neoplasms in any mammary region with satisfactory aesthetic results. They are based on original techniques that preserve the ascending and perfusing features of the nipple-areolar complex ${ }^{22}$. For conservative surgical treatments, breast cancer surgeons should take the following into consideration: local recurrence, survival rates and patient satisfaction. The application of mammoplasty techniques in the treatment of breast cancer offers an improvement in patient satisfaction, without compromising oncological outcomes ${ }^{23}$. In relation to relapses, tumors larger than $2 \mathrm{~cm}$ appear to have an increased risk of local recurrence ${ }^{24}$.

The results of oncological mammoplasty are similar to those obtained in purely esthetic reductions..$^{22}$ The proper preoperative planning should consider tumor location and the relation of the area to be resected with the total mammary volume. That will determine the technique to be applied and the location of the incisions for a satisfactory outcome both from the oncological and the aesthetic points of view. Patients affected by mammary neoplasia and with very large breasts, when submitted to oncological mammoplasty, will, in addition to the treatment of the disease, benefit from an improvement in overall quality of life. Although these patients could have a good outcome with simple conservative surgery, they constitute the group with the highest morbidity in postoperative radiotherapy, which is usually very uncomfortable due to the volume and shape of their breasts. In addition, dose homogeneity is more difficult to obtain in large breasts ${ }^{22}$.

A good preoperative evaluation (with emphasis on the resection area, incision design, possibility of immediate silhouette repair and mammary symmetry), besides providing treatment of malignant neoplasms, improves the patients' quality of life ${ }^{22}$. The basis of mastology requires the current 
professional to master surgical techniques of reductive mammoplasty, to provide a treatment with oncological safety associated with excellence in aesthetic results for a greater number of patients.

\section{Plastic surgery's point of view}

According to Sampaio ${ }^{25}$, the approach of plastic surgeons to breast surgeons, radiologists, pathologists, clinical oncologists and radiotherapists, when aiming to exchange knowledge, contributes with the multidisciplinary understanding of breast cancer. According to clinical oncology and oncoplastic breast surgery experience, the concerns that a plastic surgeon should have when performing oncoplastic surgery include:

1. awareness of the extent of the disease;

2. oncologic surgical programming and possibilities of intraoperative changes;

3. anatomopathological diagnosis and margin control;

4. radiotherapy and breast reconstruction;

5. adjuvant chemotherapy and neoadjuvant chemotherapy;

6. reconstruction aesthetic results; and

7. clinical and imaging follow-up ${ }^{25}$.

The plastic surgery principles indicate that oncological or mastological follow-up is of extreme importance for a better treatment strategy. The plastic surgeon should also be concerned about the aesthetic implications of radiotherapy treatment (which may be compromised ${ }^{26}$ ) or chemotherapy, which should start within 12 weeks after the surgical procedure ${ }^{25}$.

\section{Oncology Overview}

It is the responsibility of the surgeon to diagnose breast cancer and ensure that there is a multidisciplinary team to approach the treatment before introducing the patient in the process. Another essential component is the inclusion of the patient in the multidisciplinary team, since a consensus among professionals will result in a common agreement on the guidelines and will have an impact on the quality of care. The absence of guidelines will result in different ways of treating patients within the same team, generating lack of clarity and variability in outcomes. A database on breast cancer is essential for auditing and for surgical quality control in individual units. The objective of this database is to define standards of care towards the cure of the patient. The presence of combined protocols allows the deficiencies to be clearly identified. It is a fundamental auditing principle to change and improve the surgical practice. Delayed diagnosis of breast cancer due to poor quality of care can alter the disease stage and impact patients' survival. The oncology practitioner is, for the most part, the first point of contact for patients with symptomatic disease, who has the responsibility to adequately refer the patient to the diagnostic service. Finally, oncology advocates that it should be the basis for the oncoplastic surgeon, in order to guarantee better survival and, especially, the quality of the treatment from beginning to end. This is justified by the fact that, in the middle of their studies, oncoplastic surgeons study techniques of treatment for all types of cancer and have contact with a multidisciplinary team of professions, including radiology, radiography, pathology, surgery, nursing and medical physics.

\section{CONCLUSION}

Considering the time invested in training and thesis defense of each specialty, it is relevant that all areas involved have a minimum knowledge of cancer treatment and undergo a selective process related to a multidisciplinary surgery team before handling the neoplasia. Mastology and oncology already have an extensive curriculum, with no need for selections to be eligible for sub-specialization in oncoplasty. However, the plastic surgeon needs to perform a curricular test of medical activities directly or indirectly connected with the treatment of cancer in general, or specifically breast cancer. An additional period should be introduced in the plastic surgeon's curriculum to approach oncological theories and techniques. The commitment of oncoplasty with patients favored less invasive surgical procedures. Many of the oncoplastic techniques can be performed by other medical specialties, but, without proper professional training, they can lead to inappropriate harm to patients. According to Simmons ${ }^{7}$, it is extremely important to be flexible and adaptable to these changes in the way we care for our cancer patients.

Table 1 shows that, in Brazil, in the United States and in Europe, the specialties do not differ from each other in relation to the surgical basis of breast reconstruction or in relation to initial or advanced treatment of breast cancer. Based on these conclusions, we can suggest the following design for the formation of oncoplastic breast professionals:

1. type of training: postgraduate program, in which the graduate student will receive academic background proved by a thesis presentation;

2. training time: which can vary between 12 and 24 months, depending on the previous training;

3. number of procedures: at least 4 patients for each of the basic themes of oncoplastic training, including changes in breast volume;

4. target audience: plastic surgeons, breast surgeons and oncologists.

\section{ACKNOWLEDGEMENTS}

I, Dr. Orivaldo Gazoto Junior, thank my advisor, Dr. Douglas de Miranda Pires, and my classmates. I take them as a legacy of respect, admiration and friendship. 


\section{REFERENCES}

1. Munhoz AM. Cirurgia oncoplástica no American College of Surgeons. 2010 [cited 2015 Sept 1]. Available from: http:// cirurgiaoncoplastica.blogspot.com.br/2010/02/oncoplasticaamericancollege-of.html

2. Quinn McGlothin TD. Breast surgery as a specialized practice. Am J Surg. 2005;190(2): 264-8.

3. Gil AC. Como elaborar projetos de pesquisa. $4^{\mathrm{a}}$ ed. São Paulo: Atlas; 2002 [cited 2016 Apr 30]. Available from: https:// professores.faccat.br/moodle/pluginfile.php/13410/mod_ resource/content/1/como_elaborar_projeto_de_pesquisa_-_ antonio_carlos_gil.pdf

4. Urban CA. Resultados da oncoplástica no tratamento conservador em câncer de mama. Tese [Doutorado]. Curitiba: Universidade Federal do Paraná. Setor de Ciências da Saúde; 2004.

5. Mazzei R. Oncoplástica: Ensino e treinamento. Soc Bras Mastol. 2010 [cited 2016 Feb 25];85(6). Available from: http:// docplayer.com.br/5992543-Editorial-cirurgiaoncoplastica-damama.html

6. Baildam AD. Oncoplastic surgery of the breast. Br J Surg. 2002;89:532-3.

7. Simmons RM. Breast surgery: past, present, and future. Am J Surg. 2000;180(4):246-8..

8. Birido N, Geraghty JG. Quality control in breast cancer surgery. Eur J Surg Oncol. 2005;31(6):577-86.

9. Rutgers EJ. Guidelines to assure quality in breast cancer surgery. Eur J Surg Oncol. 2005;31(6):568-76.

10. Miguelena JM, Cunchillos FD. Training in breast surgery in Spain. Cir Esp. 2016;94(6):323-30.

11. Yunaev M, Hingston G. Oncoplastic breast surgery: a regional Australian 2012 fellowship experience. ANZ J Surg. 2013;83(9):624-9.

12. Nicolaou PK, Padoin LV. O retrato das políticas públicas no tratamento do câncer de mama no Brasil. Rev Bras Mastol. 2013;23(3):92-4.

13. Brasil. Jornal do Senado. Lei obriga reconstrução de mama [Internet]. 2013 [cited 2014Jan 25]. Available from: http://www12. senado.leg.br/jornal/edicoes/2013/05/07/jornal.pdf/view

14. Hartt V. Em defesa da Oncoplástica. Onconews. [Internet]. 2014 [cited 2016 Feb 25]. Available from: http://www.onconews. com.br/site/index.php?option=com_content\&view=article\&i $\mathrm{d}=612 \&$ catid $=131 \&$ Itemid $=586$

15. Machado MH. Os médicos no Brasil: um retrato da realidade. Rio de Janeiro: Fiocruz; 1997. 244 p.
16. Roberts JM, Clark CJ, Campbell MJ, Paige KT. Incidence of abnormal mammograms after reduction mammoplasty: implications for oncoplastic closure.AmJSurg.2011;201(5):611-4.

17. Zucca-Matthes G. Cirurgia Oncoplástica da mama. Rev Onco. 2013:36-9.

18. Sanchéz MD, Rubiano MD. Cirurgía Oncoplástica en Cáncer de Mama. Rev Colombiana Cir. 2008 [cited 2016 Feb 25];23(4). Available from: https:/encolombia.com/medicina/revistasmedicas/cirugia/vc-234/cirugiaoncoplastica

19. Cosac OM, Camara Filho JPP, Cammarota MC, Lamartine JD, Daher JC, Borgatto MS, Esteves BP, et al. Reconstrução mamária de resgate: a importância dos retalhos miocutâneos. Rev Bras Cir Plást. 2013;28(1):92-9.

20. Instituto Nacional de Câncer José Alencar Gomes da Silva (INCA). Incidência de Câncer no Brasil - Estimativa 2016: Síntese de Resultados e Comentários. 2016 [cited 2016 Abr. 12]. Available from: http://www.inca.gov.br/estimativa/2016/ sintese-de-resultados-comentarios.asp

21. Vieira RAC, Matthes AGZ, Matthes ACS, Haikel RL, Bailão Júnior A, Mendonça MLH de, et al. A oncoplastia e o tempo de treinamento do cirurgião. Rev Bras Mastol. 2010;20(2):66-70.

22. Schuh F, Biazús JV, Resetkova E, Benfica CZ, Edelweiss MI. Reproducibility of three classification systems of ductal carcinoma in situ of the breast using a web-based survey. Pathol Res Pract. 2010;206(10): 705-11.

23. Resende MA. Reflexões Oncoplásticas aos Mastologias Brasileiros. Rev Bras Mastol. 2012;22(1):1-2.

24. Asgeirsson KS, McCulley SJ, Pinder SE, Macmillan RD. Size of invasive breast cancer and risk of local recurrence after breast-conservation therapy. Eur J Cancer. 2003;39:2462-9.

25. Sampaio MMC. Oncologia clínica e cirurgia oncoplástica da mama. Soc Bras Mastol. 2010;85:3-4.

26. Motwani SB, Strom EA, Schechter NR, Butler CE, Lee GK, Langstein HN, et al. The impact of immediate breast reconstruction on the technical delivery of postmastectomy radiotherapy. Int J Radiat Oncol Biol Phys. 2006;66(1):76-82.

27. Cardoso MJ, Macmillan RD, Merck B, Munhoz AM, Rainsbury R. Training in oncoplastic surgery: an international consensus. The 7th Portuguese Senology Congress, Vilamoura, 2009. Breast. 2010;19(6) 538-40.

28. Mesquita M. Cirurgia Oncoplástica da Mama [Trabalho de Conclusão de Curso]. Rio de Janeiro: Universidade Federal do Rio de Janeiro; 2014.

29. Resende, MA. Reflexões oncoplásticas aos mastologistas brasileiros. Rev Bras Mastologia. 2012;22(1):1-2. 